\title{
To the Question About the Features of Phraseological Units with a Zoonym Component in the Function of Interjections in English, French, and Russian
}

\author{
Maklakova Y.M. \\ Foreign languages department \\ Kazan (Volga Region) Federal University Naberezhnye Chelny \\ Institute \\ Naberezhnye Chelny, Russia \\ emmaklakova@kpfu.ru
}

\author{
Magfurova S.O. \\ Law and humanities department \\ Naberezhnye Chelny branch University of management «TISBI» \\ Naberezhnye Chelny, Russia \\ svmag65@gmail.com
}

\author{
Khuzin I.R. \\ Philology department \\ Kazan (Volga Region) Federal University Naberezhnye Chelny Institute \\ Naberezhnye Chelny, Russia \\ ilnurkhuzin@mail.ru
}

\begin{abstract}
In the article, within the framework of the comparative phraseology theory, the authors consider semantic and structural-grammatical features of interjective phraseological units with zoonym component in English, French and Russian languages. From the point of semantics view, the studied language material of three languages of different structure represents exclamations with negative coloring. Structurally, these units are presented with non-predicative, predicative and partially predicative structure. The scope of the praseological units concept, in addition to nominative, includes communicative units (proverbs, winged expressions, etc.). As a result of comparative analysis in a separate group attributed interjective phraseological units, combining features of interjections and other parts of speech.
\end{abstract}

Keywords-interjection; interjectional phraseological units; zoonyms; paremiology.

\section{INTRODUCTION}

In comparative phraseology, the number of phraseological units with a zoonym component has a great historical and cultural potential, since it contains a clearly expressed emotional and expressive native speakers' assessment of a reality's phenomena of in the context of a particular era. We believe that the fund of analyzed phraseological units of English, French and Russian cultures acts as one of the key codes and is used in the description of various spheres of human activity. In connection with the multi-aspect approach to the definition of the status and scope of the phraseological units concept, of particular interest to us are the phraseological units with a zoonym component in the function of interjections
(IPU) at the level of the communicative act and having a pronounced colloquial-expressive stylistic coloration. This is what in many ways makes IPU with a zoonym component the origin of which is directly related to the oral folk art.

The purpose of this article is to present the comparative analysis of phraseological units with a zoonym component in the function of English, French and Russian interjections.

\section{LITERATURE REVIEW}

Although different aspects of phraseological units with a zoonym component are examined by linguists and researchers $[8 ; 11 ; 14 ; 17]$, phraseological units with a zoonym component in the function of interjections are not under a specific examination yet.

IPU, being a direct reaction to the words of the interlocutor or the speech situation in general, have a high degree of emotionality. At the level of phraseological turns of speech IPU have semantic and syntactic properties of interjections [10]. As for the syntactic role of interjections, in the structure of sentences they function not as its members, but as independent and separate units [12].

The difference between IPU and interjections is noted by a Russian linguist who writes that depending on the purpose of use IPU realize the communicative functions of expressing attitudes to the situation, evaluation, emotional state and catharsis, but interjection statements are used as a means of mental relaxation, means of getting rid of negative experiences [18]. Different linguists distinguish various semantic groups of 
IPU which can express feelings or incentive value in the form of encouragement, threat, inducements, wishes, warnings etc. $[7 ; 19 ; 20]$.

\section{METHODOLOGY OF RESEARCH}

In this paper such theoretical methods have been used: descriptive method including observation, interpretation, comparison, generalization and method of simultaneous analysis of linguistic facts.

\section{RESULTS}

The corpus of phraseological units with a zoonym component in three languages was selected, allowing in a separate group include praseological units, combining the characteristics of interjections and other parts of speech. The main features of phraseological units with zoonym component such as integral figurative meaning, reproducibility, imagery and expressiveness and these phraseological units have different structures (levels) and determine the presence of two phraseological concepts in linguistics. According to the first concept, the subject of phraseology is outlined by the level of nominative units, interpreted as stable combinations, semantically transformed connections of words, correlated with the word. According to another concept, the boundaries of phraseology are significantly expanded by semantically transformed stable combinations at the sentence level. In this case, the phraseology, except the nominative, includes communication units as well: proverbs, sayings, etc. Linguists accept the phraseological units to be separate units of language with fully or partially reinterpreted meaning, or to be what is expressed figuratively, comparisons with the appropriate meaning of figurative words and even entire expressions, expressions in the form of individual phrases, proverbial expressions, sayings, proverbs and well-known quotes $[1 ; 14]$. According to a Russian linguist proverbs refer to language signs that formally meet all the requirements for such relatively stable complexes as phraseological units (a certain degree of idiomaticity, reproducibility in speech in the finished form, the relative stability of the component composition) [16].

It should be noted that the typical structural models of the analyzed languages sayings correspond to a general typical situation describing a certain state of affairs in the reality surrounding native speakers. We will demonstrate this in the following examples. So, the design of the "NImperV $+\mathrm{N}+\mathrm{V}$ " in the English language that models such Proverbs as: Don't teach fish to swim, Don't teach the dog to bark, Don't teach the cock to crow, Don't teach a hen to cluck, Don't teach a serpent to hiss with the Russian counterparts, "do Not teach a pike to swim," "do Not teach the dog to bark", matches the common typical situation - "you should Not teach knows his job man". And the situation "Everyone should do their own thing and not to get into the affairs of others" is represented by sayings of English and Russian languages, having the same type of construction. The English language is "ImperV+Adj+N+V+(Pron/Prep)+Pron+(Adj)+N": Let every man skin his own eel; Let every pig dig for himself; Let every fox take care of his own brush; Let every herring hang by its own gill/tail (sheep hang by its own shank); Let every tailor stick to his goose; Let every sheep hang by its own shank. And in the Russian language - the Proverbs of the structure "ImperV+N+Adj+N": Знай сверчок свой шесток [let the cricket stick to its hearth], Знай кошка свое лукошко [a cat must know cat his basket], Знай ворона свое гнездо [a raven must know his nest]. In total, we have identified 14 typical situations of social and moral and instructive nature, represented by the same type of Proverbs and sayings with the names of animals on the basis of the English, French and Russian languages material.

In General, the structural-grammatical approach to the study of zoonym phraseology, based on structural-semantic classification of phraseological units with the consideration of the functional characteristic allowed to identify six structural types, namely verbal, substantive, adjectival, adverbial, interjection and communication phraseological units. Among the most numerous group of phraseological units with the zoonym component - verbal one - in the compared languages we identified six single-type structural models: "V+N, $\mathrm{V}+\mathrm{Prep}+\mathrm{N}, \quad \mathrm{V}+\mathrm{N}+$ Prep $+\mathrm{N}, \quad \mathrm{V}+\mathrm{Adj}+\mathrm{N}, \quad \mathrm{V}+\mathrm{Comp}+\mathrm{N}$, "V+Comp+N+Prep+N". As a reference component in the comparative constructions that directly represent anthropological field of zoonym phraseology, there are the verbs "to work", "is", "sing", "sleep" (for the three languages), "live", "to twist/slide" (for French and Russian), the verbs "play/act", "have", "be", "go", "get", "ride", "see", "put/set" (for English), the verbs "faire", "avoir", "prendre", "plumer", "être", "aller", "avaler" (for French), verbs of visual perception "view", "gaze", "stare" (for Russian). Only a relatively small part of phraseological units of English, French and Russian languages is marked by a mismatch of structural organization and is represented, as a rule, by specific models of single formations that do not differ in productivity or frequency of use.

A number of phraseological dictionaries take in traditional idioms, idiomatic compound, similes and comparisons, exclamations and sayings, clichés. For instance: Don't count your chickens (before they are hatched), The early bird catches the worm, A bird in the hand (is worth two in the bush), Chicken come home to roost, Birds of a feather flock together, A cat may look at a king [4]; A bird in the hand is worth two in the bush, To escape the bear and fall to the lion, One rat brings another, To see he bears, as brisk as a beaver, as busy as bees, as fat as a bear, as gay as a bird [8; 22]; Il ne faut pas vendre la peau de l'ours (avant qu'on ne l'ait pris, avant de l'avoir tué) [bear skin is not sold until it is caught, killed] with reference to the original proverb Il ne faut pas marchander [faire commerce] la peau de l'ours devant [avant] que la beste soit prise ou morte [6]; сильнее кошки зверя нет [there is no beast stronger then a cat ], сказка про белого бычка "the Megillah”, свинья под дубом [pig under the oak tree], слона не приметить [not to notice an elephant], собака на сене "the dog in the manger", стрелять из пушек по воробьям [shoot from guns on sparrows], чтоб не дразнить гусей [not to tease the geese], попалась птичка [the bird is caught], белая ворона [white crow], блоху подковать [to shoe a flea], живая собака лучше мертвого льва "a live dog is better than a dead lion" $[3 ; 2 ; 5 ; 13]$.

\section{DISCUSSION}

In our view, some of the examples given above may raise doubts about their attribution to the IPU. We should pay attention to the fact that the formal indicator of the distinction between IPU and communicative phraseological units with the structure of the sentence, is "the possibility of including communicative phraseological units in the sentence as its 
integral part, while for interjectional phraseological units, such a possibility typically is excluded» [20]. A large layer of phraseological units, as proverbs, traditionally related to communicative phraseological units, can act as a "separate sentences or parts of complex sentences" [10]. Taking into account these criteria allows a separate group to include phraseological units, combining the features of interjections and some other parts of speech and thus having a blurring of categorical boundaries. This group is formed by, for example, IPU in a pig's ass/eye/ear! "the pipes! hell no!; never!" (an expression expressing distrust), свинья свиньей, идет коза рогатая, думает <только> индейский петух (да генералы), это и кошку рассмешит.

Reasoning about structural and grammatical features of the French language IPU, A. G. Nazaryan notes that "most of the interjectional phraseological units has a predicative structure" and that "interjectional phraseological units with partly predicative structure is not peculiar to the French phraseology" [15]. Still we note the example of an IPU with partly predicative structure: cochon qui s'en dedit! i.e. "by God!".

In General, the analysis of the investigated material of the French language showed that predicative IPU are represented mainly by two-part sentences that start with presentative "s'est" [it is] in the affirmative or "ce n'est/C'est pas" [it is not] in the negative: ce n'est/C'est pas cochon <du tout> [it is not a pig] "this is not bad, that's good, that's what we need, though," C'est boeuf! [it is beef] "that's great!", C'est (ce sera) le chien pour (it is a dog for) "like hell", C'est le chat! [it is a cat] (ironic response to the attempt to justify himself), C'est la vache! [it is a cow] "that's not luck, it's disgusting", s'est chouette [it is an owl] "this is nice! lovely!".

Thus, IPU, depending on the context, expressing the entire spectrum of emotions and feelings - from purely positive to extremely negative - have an invariant emotional-evaluative meaning of interjections. Moreover, a large number of analyzed IPU with a zoonym component in the compared languages have a negative emotive value, which largely indicates the nominal nature of their semantics. As for the structural-grammatical peculiarities of IPU, the formal indicator of the distinction between communicative phraseological units and IPU with the structure of the sentence, is the inclusion of communicative phraseological units in the sentence as its component parts, while IPU receive the status of an independent separate units. In view of these criteria the corpus of phraseological units with a zoonym component based on a specific linguistic material was selected, allowing in a separate group include praseological units, combining the characteristics of interjections and other parts of speech. We believe that the existence of such units testifies to the semantic and structural - grammatical characteristics of the language as a multifunctional system, the different sides of which are interconnected and interdependent.

\section{CONCLUSIONS}

Sayings and proverbs, which are the object of paremiology research, often have the structure of a simple or compound sentence. Paremiology is traditionally understood as "philological discipline that studies the sayings of different kinds, especially folk ones» [21]. Accordingly the object of study in this scientific field is the various proverbs, sayings, riddles, proverbial signs, etc. Fundamental in this case is the question of whether paroemia is a unit of language, i.e. whether it is possible to classify it as a phraseological unit. More convincing is the point of view of the well-known researcher of structural paremiology, G. L. Permyakov, according to which the proverbs refer to linguistic signs, which formally satisfy all the requirements for such a relatively stable complexes as phraseological units (a certain degree of idiomaticity, reproducibility in speech ready-made, the relative stability of the component composition) [16]. The basis of the proverb is a logical content that conveys the different relationships between things in real life. However, some proponents of a broad approach to the concept of phraseological units argue that not all proverbs can be ranked among the objects of phraseology. This is mainly due to the fact that different scientists take different principles as the basis for the selection of proverbs included in the phraseological fund. So, M. D. Stepanova, I. I. Chernysheva base on the frequency of proverbs use (Stepanova, Chernysheva 1986), D. V. Yurchenko on the principle of matching the formal criteria of phraseological units, namely a metaphorical reinterpretation (Yurchenko 2007), and E. F. Arsentyeva on the principle of proverbs imagery (Arsentyeva 1989). Note that the points of view of D. V. Yurchenko and E. F. Arsenyeva, which have a common basis, are commensurate with the principle of proverbs selection in this study. Since imagery, created through metaphorical reinterpretation, is an objective criterion determining the occurrence of proverbs in the composition of phraseological units the authors believe that it is not justified to deprive proverbs of status of phraseological units due to a decrease in their communicative significance. However, according to A.V. Kunin, "proverbs with the literal value of all components refer to stable entities phraseomatic character" [9].

In this paper, following A. A. Kuptsova, under IPU we understand such "interjection phraseological unit", which "have the characteristics of interjections", i.e. "serve to express different feelings, emotions, volitional impulses individuals have the same syntactic properties as interjections" [11]. Thus, most of the IPU of compared languages have a pronounced emotional and evaluative value and convey a whole range of human feelings and emotions: surprise, disappointment, condemnation, admiration, etc. Syntactically, IPU are not members of the sentence and act as independent and separate speech units, separated by punctuation marks on the letter.

In this regard, we give examples of IPU with a componentzoonym that meet these criteria: A l'ours "get away!", A la chouette! "goody!", От верблюда! [From a camel!], Едят тебя мухи! [Flies eat you!] Пес его знает! [The dog knows him!] Пес с ним! [Dog with him!].

It should be noted that a number of researchers (N. F. Alefirenko, D. A. Tishkina) also refer interrogative and affirmative turns to the IPU. Among IPU with a componentzoonym in the English and Russian languages D. A. Tishkina distinguishes two main groups:

1) the structure of the phrase: watch the birdie (or the dicky-bird)! "look at the bird!"(so say photographers, when take photos of children); stiffen the lizards (snakes or wombats); starve the lizards! (or starve the mice, the rats, the sparrows, or wombats!) “ $\approx$ dammit! damn it!”; свинья свиньей 1) dirty, careless, extremely careless person; 2) low, vile, ungrateful and dishonest person; курицын сын (курицына дочь, курицыны дети) [son of a chicken 
[10] Kunin, A.V. Phraseology Course of the modern English

(daughter of a chicken, children of a chicken)] "used as an expletive ";

2) with the structure of a sentence, for example: are you there with your bears? "are you doing the same here? the same again?"; has the cat got your tongue? "have you swallowed your tongue?"; who's afraid of the big bad wolf? "we are not afraid of the gray wolf", i.e. we are afraid of nothing and no one [words from the song in the cartoon U. Disney's 'Three little pigs' (1931)]; Это и кошку рассмешит [It makes a cat laugh] "impossible to keep from laughing, about a ridiculous situation"; Пошли они к козе на именины! used as an invective; думает <только> индейский петух (да генералы) [thinks < only> Indian cock (and generals)] "it is said in response to the justification: 'I thought...'and others [17].

\section{References}

[1] Arsentieva, E.F. Phraseology and phraseography in comparative aspect (on the material of Russian and English languages). Kazan: KFU. 2006, p.3.

[2] Ashukin, N.S., Ashukina, M.G. Winged words. Literature citations. Figurative expressions, M.: Pravda. 1986.

[3] Birikh, K. Russian phraseology. Historical-etymological dictionary: approx. 6000 idioms. M.: Astrel: AST: Keeper. 2007.

[4] Cambridge International dictionary of idioms. Cambridge: Cambridge University Press. 1998.

[5] Dal, V.I. Proverbs and sayings of the Russian people. Moscow: Eksmo. 2008.

[6] de Chantreau S., Rey, A. Dictionnaire des expressions et locution's. Dictionnaires Le Robert. 2007.

[7] Guiliazeva, E.N., Bazarova, L.V., Billialova, A.A. Semantic features of phraseological units expressing emotions and feelings of a person in German and Russian languages, Modern journal of language teaching methods (MJLTM), Iran. 2018, vol. 8(11), pp. 231-236.

[8] Kulichenko, Yu.N., Korolevskaya, E.M. Comparative Analysis of Phraseological Units with the ComponentZoonym. Nauchnyy dialog. 2017, vol. 4, pp. 44-56.

[9] Kunin, A.V. Course of phraseology of modern English: Studies: for institutions and foreign languages departments. Moscow: "Phoenix". 1996, p.177. language: for institutions and foreign languages departments. 2005.

[11] Kuptsova, A.A. Interjectional units with the component "God" : the structural-semantic and cognitive aspects. Candidate's thesis. Irkutsk. 2010, p.30.

[12] Litovkin, A.V. Interjection phraseological units: semantic, structural-syntactic and functional features: based on Russian and German languages. Candidate's thesis. Saratov. 2005.

[13] Melerovich, A.M., Mokienko, V.M. Idioms in the Russian language: Vocabulary: approx. 1000 units. Moscow: Russian dictionaries: Astrel: AST. 2005.

[14] Mizhaeva, M.O. Phraseological units with the animal component in the Kabardino-Circassian language. Candidate's thesis. Cherkessk. 2003, p.10.

[15] Nazarian, A.G. Phraseology of modern French. Moscow. 1987, p. 121.

[16] Permyakov, G.L. Fundamentals of structural paremiology. Moscow. 1988.

[17] Tishkina, D.A. Phraseological units with the zoonym component in English and Russian: a comparative analysis. Candidate's thesis. Kazan. 2008, p. 69-70.

[18] Trubina, O.B. Slang and colloquial elements in the function of interjection statements. Candidate's thesis. Moscow. 1993.

[19] Alefirenko, N.F., Semenenko, N.N. Phraseology and paremiology: textbook for bachelor's level of philological education. M. Flinta: Nauka. 2009.

[20] Nazaryan A.G. Phraseology of modern French: studies. for universities. Moscow: Higher school. 1976, p.148.

[21] Yurchenko, D.V. Structural-semantic and nominative motivational properties of zoonym praseological units in German language. Candidate's thesis. Pyatigorsk. 2001, p.33.

[22] Whiting, J. Early American proverbs and proverbial phrases. USA. 1977. 